\title{
MODELING EXCHANGE RATE VOLATILITY IN CEEC COUNTRIES: IMPACT OF GLOBAL FINANCIAL AND EUROPEAN SOVEREIGN DEBT CRISIS
}

\begin{abstract}
The aim of this study is to envisage the impact of global financial (GFC) and European sovereign debt crisis (ESDC) on foreign exchange markets of emerging countries in Central and Eastern Europe CEEC countries (Czech Republic, Hungary, Romania, Poland and Serbia). The daily returns of exchange rates on Czech Republic koruna (CZK), Hungarian forint (HUF), Romanian lea (ROL), Polish zloty (PLZ) and Serbian dinar (RSD), all against the Euro are analyzed during the period from $3^{\text {rd }}$ January 2000 to $15^{\text {th }}$ April 2013, in respect. To examine the impact of global financial crisis and European sovereign debt crisis, dummy variables were adopted. Overall results imply that global financial crisis has no impact on exchange rate returns in selected CEEC countries, while European sovereign debt crisis influencing in depreciation of Polish zloty by $8 \%$ and Romanian lea by $6 \%$. Obtained results by our calculation, imply that global financial crisis increased enhanced volatility on exchange rate returns of Czech koruna, Romanian lea and Polish zloty. Moreover, results of empirical analysis imply that this impact has the strongest influence in volatility on exchange rate returns of Polish zloty.
\end{abstract}

Key words: exchange rate, volatility, global financial crisis, european sovereign debt crisis, CEEC countries

\section{Introduction}

Foreign exchange market is the world's largest financial market with no opening or closing hours. An investor's confidence to invest in particular country is inversely related to high volatilities in exchange rate. This is the basic reason why volatility models are used to explain the enduring and significant instance in the foreign exchange rate movements (Kamal et.al.,2012). Poon and Granger (2003) asserted that financial volatility has significant influence on the

Assistant Professor Siniša Miletić, PhD, Faculty of Business Economics and Entrepreneurship,

Belgrade, e-mail: sinisamiletic72.bgd@gmail.com 
economy hile the policy and decision makers depend heavily upon the volatility modeling anticipation on the vulnerabilities of financial markets and economy.

The traditional measure of volatility as represented by variance and standard deviation is unconditional and does not recognize interesting patterns in asset volatility, e.g., time-varying and clustering properties (Olowe,2009). Researchers have introduced various models to be able to explain and predict these patterns in volatility. One such approach is represented by time-varying volatility models which were expressed by Engle (1982) as autoregressive conditional heteroscedasticity (ARCH) model and extended by Bollerslev (1986) into generalized ARCH (GARCH) model. These models recognize the difference between the conditional and the unconditional volatility of stochastic process, where the former varies over time, while the latter remains constant (McMillan and Thupayagale 2010).

Recent global financial crisis is a major turmoil event which permeated all over the world irrespective of developed or emerging countries. The magnitude of the turmoil appears all the more severe since it is not confined to a certain region or country. It was rooted when the Information Technology bubble burst, causing the federal government to deregulate and cut interest rate. Cheap credit enabled even subprime borrowers with low creditworthiness to become homeowners. Profit-driven investors recklessly traded various derivatives such as Mortgage Backed Securities since US housing prices grew rapidly for years. However, excessive securitization of mortgages caused a bubble in the housing market and aggravated the difficulty of risk assessment. The bubble inflated further when interest rates rose, resulting in a surge in defaults by subprime borrowers. The companies that traded structured products backed by mortgages experienced massive loss as the bubble burst. Various financial institutions were hit by the crisis, which by then was no longer merely a problem of the US. The collapse of US financial institutions dealt a critical blow to other industries. The US housing market went into a recession and financial institutions that dealt in mortgage-backed derivatives defaulted. Furthermore, overseas financial institutions with direct or indirect investment in derivatives fell into a crisis of their own. As financial institutions rushed to withdraw investment, emerging economies highly dependent on foreign capital were distressed and value of dollar shot up. The capability of emerging economies to return short-term foreign debt decorated, forcing Iceland, Ukraine, Hungary and Pakistan to turn to the IMF for bailout. To emerging economies heavily depend on foreign capital and exportdriven economies, the rise of dollar loomed as a grave threat (Chang et.al., 2010).

Financial crises affecting the sudden and unexpected fluctuations in exchange rates and emphasize the importance of measuring the foreign exchange rate volatility. The volatility of foreign exchange rates results in increase of exchange rate risk and adversely affects the international trade and investment decision (Kamal et.al., 2012). 
The aim of this study is to envisage the impact of global financial (GFC) and European sovereign debt crisis (ESDC) of selected emerging countries in Central and Eastern Europe (CEEC) countries (Czech Republic, Hungary, Poland and Serbia). The paper applies symmetric GARCH and three asymmetric GARCH models, which are EGARCH, TGARCH and APARCH with variations in their mean equations: $\mathrm{AR}(1), \mathrm{MA}(1)$, and $\mathrm{ARMA}(1,1), \mathrm{ARCH}$ in mean thet capture most stylized acts about exchange rate returns such as volatility clustering and leverage effect. The exchange rate volatility is measured throughout the period during global financial and sovereign debt crisis to find out whether these crises affect the volatility the exchange rate volatility in selected CEEC countries.

The working paper is structured as follows. Literature review is presented in the second chapter. In third chapter GARCH type methodology is presented. The fourth chapter presents the results of empirical analysis. Finally, concluding remarks are given in the fifth chapter.

\section{Literature review}

Although there have been an extensive empirical studies focusing on modeling and estimating exchange rate volatility in developed countries applying different specification little attention has been paid on emerging countries.

Chong et.al. (2002) investigates application of GARCH models to capture exchange rate volatility in Malaysian Ringgit/Pound Sterling, for 1990-1997 period. Results of empirical investigation suggest the possibly reject the hypothesis of constant variance model, arguing that the GARCH models were better once than native random walk models. Longmore and Robinson (2004), applied linear GARCH and asymmetrical volatility models on Jamaican Dollar for 19982003 period and found long memory process for the exchange rate with effects of shocks being asymmetric, while in terms of explanatory power, the non-linear GARCH model performed well.

Olowe (2009), used a number of GARCH models to investigate the volatility of Naira/US Dollar exchange rate in which the hypothesis of leverage effect was rejected by all asymmetric models, though all the coefficients of the variance equations were significant, the TS-GARCH and APARCH models proved to be the best models. On the other hand, EGARCH model showed that in Nigerian foreign exchange market, with all variances being non-stationary, the volatility is highly persistence. Suliman (2012), consider the GARCH approach in modeling exchange rate volatility in a panel of 19 of the Arab countries using daily observations over 2000 to 2011 period. Author applies both symmetric and asymmetric models to capture most common stylized facts about exchange rate returns such as volatility clustering and leverage effect. The results show that based on GARCH $(1,1)$ model, that for ten of nineteen currencies sum of the estimated 
persistent coefficient exceed one implying that volatility is an explosive process. Furthermore, the asymmetrical EGARCH $(1,1)$ results provide evidence of leverage effect for majority of currencies, indicating that negative shocks imply a higher next period volatility than positive shocks.

Exchange rate volatility in CEEC's countries is analyzed by several authors. Kobor and Szekely (2004) use a Markov regime-swithing model for four foreign exchange markets in the period 2001 to 2003 whilst indentifying two volatility regimes in which the between-market cross-correlations differ significantly. Kočenda and Valachy (2006) finds that exchange rate volatility generally increased with the introduction of more flexible exchange rate arrangements. Fidrmuc and Horvath (2007) examined the daily exchange rate dynamics in selected new EU memeber states ( Czech Republic, Hungary, Poland, Romania and Slovakia) using GARCH and TARCH models between 1999 and 2006. Authors find that the low credibility of exchange rate managements tried to manage their exchange rate. Authors find that the low credibility of exchange rate management implied higher volatility of exchange rates when it substantially deviated from the imlicit target rates for all countries. Furthermore, authors find significant asymmetric effects of volatility of exchange rates in all analyzed countries.

Schnabl (2008) investigates the impact of exchange rate stability on growth for a sample of 41 mostly small open economies in the EMU periphery. Based on panel estimations author revealed a robust negative relationship between exchange rate volatility and growth for countries in the economic catch-up process with open capital accounts.

Frommel (2010) analyzed to what extent the volatility regime modifications of five markets (Czech Republic, Hungary, Poland, Romania and Slovakia), are related to the changes in official exchange rate arrangements. Using GARCH and the Markov switching models, author showed that this relationship is stronger for Hungary and Poland, less so for the Czech Republic, whereas unclear for Romania and Slovakia. Todea and Platon (2012) investigated sudden changes in volatility of four Central and Eastern European foreign exchange markets (Czech Republic, Hungary, Poland and Romania) using the Iterated Cumulative Sums of Squeres algorithm and re-examines the volatility persistence during the period 1999 to 2009. Authors determined that the identification of sudden exchanges is associated with local financial, economic and political events, with the exception of the financial crisis as a global factor. Accounting for these sudden shifts in volatility in the GARCH models significantly reduces the persistence of volatility or long memory in the Central and Eastern Europe foreign exchange markets. 


\section{GARCH type models}

The GARCH type models successfully capture several characteristics of financial time series, such as thick tailed returns and volatility clustering. A general GARCH(p,q) model proposed by Bollerslev (1986) can be written in the following form:

$$
\begin{aligned}
& y_{t}=a_{0}+\sum_{i=1}^{m} a_{i} y_{t-i}+\varepsilon_{t}-\sum_{j=1}^{s} b_{j} \varepsilon_{t-j} \\
& \varepsilon_{t}=z_{t} \sigma_{t}, \varepsilon_{t} \mid I_{t-1} \sim N\left(0, \sigma_{t}^{2}\right) \\
& \sigma_{t}^{2}=\alpha_{0}+\sum_{i=1}^{q} \alpha_{i} \varepsilon_{t-i}^{2}+\sum_{j=1}^{p} \beta_{j} \sigma_{t-j}^{2} \\
& \alpha_{0}>0, \alpha_{i} \geq 0, \beta_{j} \geq 0, i=1, \ldots, q, j=1, \ldots, p
\end{aligned}
$$

The first equation actually describes the percentage level of return, $y_{t}=100^{\star} r_{t}$ which is presented in the form of autoregressive and moving average terms, i.e. $\operatorname{ARMA}(\mathrm{m}, \mathrm{s})$ process. Error term $\varepsilon_{t}$ in the first equation is a function of , which is random component with the properties of white noise. The third equation describes the conditional variance of return, , which is function of $q$ previous periods and conditional variance of $p$ previous periods. The stationarity condition for $\operatorname{GARCH}(\mathrm{p}, \mathrm{q})$ is $\sum_{i=1}^{q} \alpha_{i}+\sum_{i=1}^{p} \beta_{i}<1$

Size of parameters $\alpha$ and $\beta$ in the equation determines the observed shortterm volatility dynamics obtained from series of returns. The high value of coefficient $\beta$ indicates that shocks to conditional variance need a long time to disappear, so the volatility is constant. The high value of the coefficient $\alpha$ mean that volatility reacts intensively to changes in the market.

I $f \sum^{q} \alpha_{i}+\sum^{p} \beta_{i}<1$, for a sufficiently long horizon forecasts conditional variance of GARCH (p, q) process:

$$
\sigma_{t}^{2}=\alpha_{0}\left(1-\sum_{i=1}^{q} \alpha_{i}-\sum_{j=1}^{p} \beta_{j}\right)^{-1}
$$

is called unconditional variance of GARCH $(\mathrm{p}, \mathrm{q})$ process.

By standard arguments, the model is covariance stationary if and only if all the roots of $\operatorname{lie} \sum_{\mathrm{i}=1}^{\mathrm{q}} \alpha_{\mathrm{i}}+\sum_{\mathrm{j}=1}^{\mathrm{p}} \beta_{\mathrm{j}}=1$ outside the unit circle. In many applications 
with high frequency financial data the estimate for $\sum_{i=1}^{q} \alpha_{i}+\sum_{j=1}^{p} \beta_{j}$ turns out to be very close to unity. This provides an empirical motivation for the so-called integrated GARCH(p,q), or IGARCH(p,q), model [see Bollerslev et al. (1994)]. In the IGARCH class of models the autoregressive polynomial in equation (2) has a unit root, and consequently a shock to the conditional variance is persistent in the sense that it remains important for future forecasts of all horizons. A general IGARCH (p, q) process can be written in the following form:

$$
\sigma_{t}^{2}=\alpha_{0}+A(L) \varepsilon_{t}^{2}+B(L) \sigma_{t}^{2}, A(L)+B(L)=1
$$

where $\mathrm{A}(\mathrm{L})$ and $\mathrm{B}(\mathrm{L})$ are lag operators.

In order to capture asymmetry Nelson (1991) proposed exponential GARCH process or EGARCH for the conditional variance:

$$
\log \left(\sigma_{t}^{2}\right)=\alpha_{0}+\sum_{i=1}^{\infty} \pi_{i} g\left(\frac{\varepsilon_{t-i}}{\sigma_{t-i}}\right)
$$

Asymmetric relation between returns and volatility change is given as function $g\left(\frac{\xi_{t}}{\sigma_{t}}\right)$ which represent linear combination of $\frac{r_{t}}{\sigma_{t}}$ and $\frac{r_{t}}{\sigma_{t}}$ :

$$
g\left(\frac{\varepsilon_{t}}{\sigma_{t}}\right)=\theta\left(\left|\frac{\varepsilon_{t}}{\sigma_{t}}\right|-E\left|\frac{\varepsilon_{t}}{\sigma_{t}}\right|\right)+\gamma\left(\frac{\varepsilon_{t}}{\sigma_{t}}\right)
$$

where and are constants.

By construction, equation is a zero mean process (bearing in mind that $\left.Z_{t}=\varepsilon_{t} / \sigma_{t}\right)$. For $0 z_{t}<\infty, \mathrm{g}\left(z_{t}\right)$, is linear function with slope coefficient $\Theta+\gamma$, while for $-\infty<z_{t} \leq 0$ it is linear function with slope coefficient $\gamma-\Theta$. First part of equation, $\Theta\left(\left|z_{t}\right|-\mathrm{E}\left|z_{t}\right|\right)$, captures the size effect, while second part, $\gamma\left(z_{t}\right)$, captures the leverage effect.

Zakoian (1994) proposed TGARCH (p,q) model as alternative to EGARCH process, where asymmetry of positive and negative innovations is incorporated in the model by using indicator function:

$$
\sigma_{t}^{2}=\alpha_{0}+\sum_{i=1}^{q}\left(\alpha_{i} \varepsilon_{t-i}^{2}\right)+\sum_{i=1}^{q}\left(\gamma_{i} d\left(\varepsilon_{t-i}<0\right) \varepsilon_{t-i}^{2}\right)+\sum_{j=1}^{p}\left(\beta_{j} \sigma_{t-j}^{2}\right)
$$

where $\gamma_{i}$ are parameters that have to be estimated, $\mathrm{d}(\cdot)$ denotes the indicator function defined as:

$$
d\left(\varepsilon_{t-i}<0\right)= \begin{cases}1, & \varepsilon_{t-i}<0 \\ 0 & \varepsilon_{t-i} \geq 0\end{cases}
$$


TGARCH model allows good news, $\left(\varepsilon_{t-1}>0\right)$, and bad news, $\left(\varepsilon_{t-1}<0\right)$ to have differential effects on the conditional variance. For instance, in the case of TGARCH $(1,1)$ process, good news has an impact of $\alpha_{1}$, while bad news has an impact of $\alpha_{1}+\gamma_{1}$. For $\gamma_{1}>0$, the leverage effect exists.

APARCH (p, q) process, proposed by Ding, Granger and Engle (1993), includes seven different GARCH type models (ARCH, GARCH, AGARCH, TGARCH, TARCH NGARCH and Log-GARCH):

$$
\sigma_{t}^{\delta}=\alpha_{0}+\sum_{i=1}^{q} \alpha_{i}\left(\left|\varepsilon_{t-i}\right|-\gamma_{i} \varepsilon_{t-i}\right)^{\delta}+\sum_{j=1}^{p}\left(\beta_{j} \sigma_{t-j}^{\delta}\right)
$$

where $\alpha_{0}>0, \delta \geq 0, \beta j \geq 0, j=1, \ldots, p, \alpha i \geq 0,-1<\gamma_{i}<1$, and $\mathrm{i}=1, \ldots, \mathrm{q}$.

Parameter in the equation denotes exponent of conditional standard deviation, while parameter describes asymmetry effect of good and bad news on conditional volatility. Positive value of means that negative shocks from previous period have higher impact on current level of volatility and otherwise.

\section{Results of empirical analysis}

The dataset consists of the daily returns of exchange rates on Czech Republic koruna (CZK), Hungarian forint (HUF), Romanian lea (RON), Polish zloty (PLZ) and Serbian dinar (RSD), all against the euro obtained from national stock exchange websites. The study covers the period from $3^{\text {rd }}$ January 2000 until $15^{\text {th }}$ April 2013, from $3^{\text {rd }}$ January 2003 until $15^{\text {th }}$ April 2013 for RSD/EUR and $3^{\text {rd }}$ January 2005 until $15^{\text {th }}$ April 2013 for ROL/EUR in respect. As in most of empirical finance literature, the variable to be modeled is percentage daily exchange rate return which is the first difference of the natural logarithm of the exchange rate, i.e. $r_{t}=\left(\log \mathrm{P}_{\mathrm{t}}-\log \mathrm{P}_{\mathrm{t}-1}\right){ }^{*} 100$. Plots of the data are presented in Figure 1.

Since the focus of this research is to examine the impact of global financial and European sovereign debt crisis dummy variable will be adopted. The decision to create dummy variables which represents the both crisis periods will be subjective and it depends on author's argument. The paper set the global financial crisis at September 2008. The reason for this is that the Lehman Brothers collapsed in middle of September, 2008. The paper set the European sovereign debt crisis at May 2011 since it was clearly visible that the Greek economy was far from being in an adequate position. Therefore, a dummy variables take 1 for the period from September 2008 to December 2009 defined as financial crisis period and, May 2011 to November 2012 defined as European sovereign debt crisis period, otherwise 0 (Miletić et.al., 2013).

Vol. 12, No 1, 2015: 105-122 
Figure 1: Daily exchange rates of national currencies vs US dollar
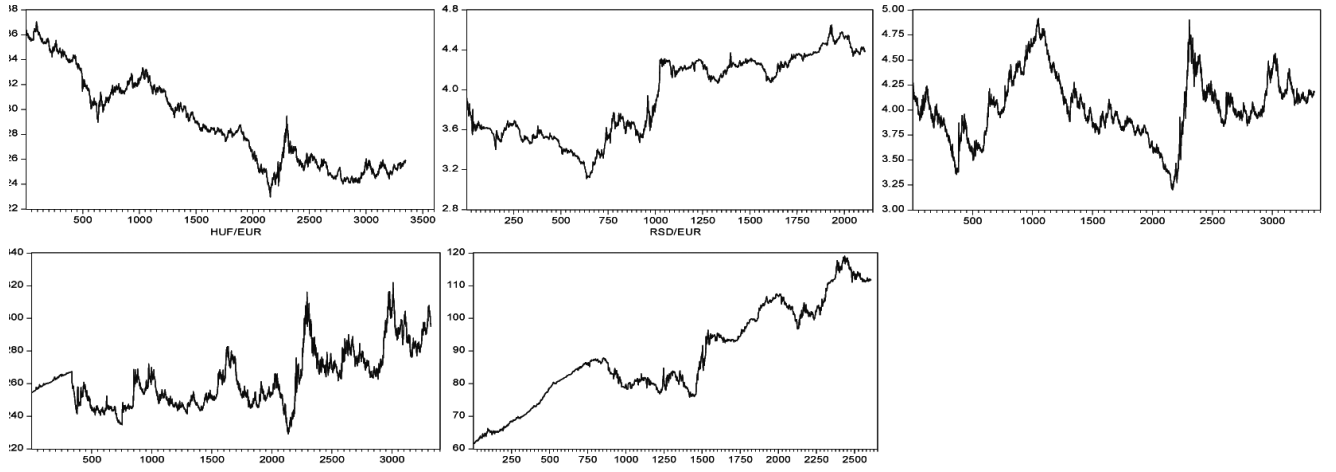

4.1. Properties of data

Bearing in mind that the one-time structural breaks may lead to erroneous statistical conclusions, in all cases we indicate the most prominent non-standard values and then regress series of returns on constant and dummy variable that take non-zero values for the observations with the most prominent nonstandard values. New adjusted series of daily exchange rate returns are used in empirical analysis (see Figure 2). Volatility clustering is clearly visible in all cases.

The quantiles of an empirical distribution are plotted against the quantiles of a normal distribution. From the Figure 3 it is clear that QQ plot is not linear and that empirical distribution differs from the hypothesized normal distribution. The plot poses the characteristic S-shape indicating that there is no significant skewnees, but the tails are havier than a normal distribition (Andersen et.al., 2000).

Figure 2: Volatility of daily exchange rate returns
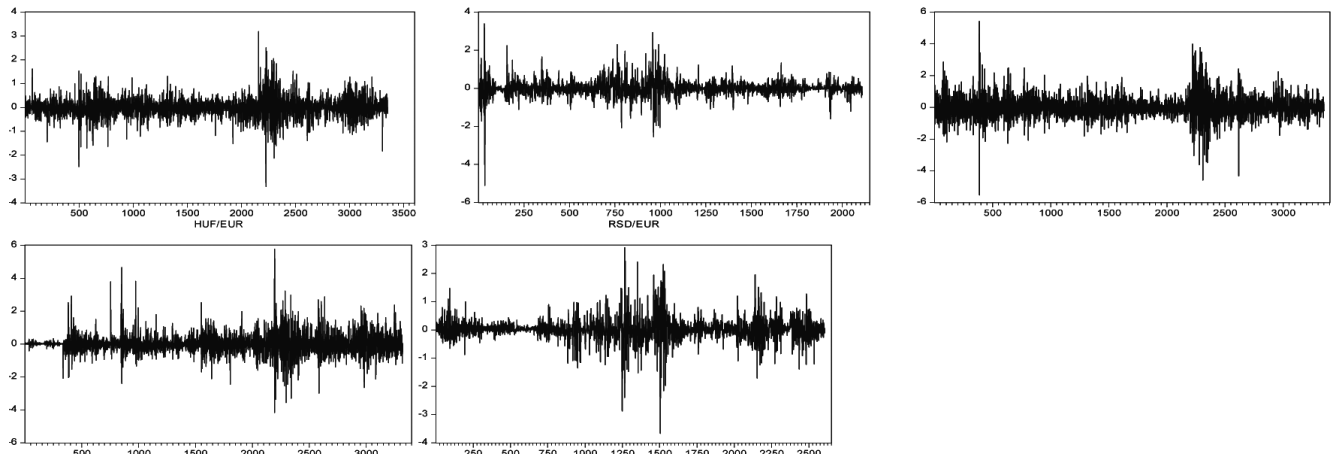
Figure 3: Quantile-quantile plots of daily exchange rate returns
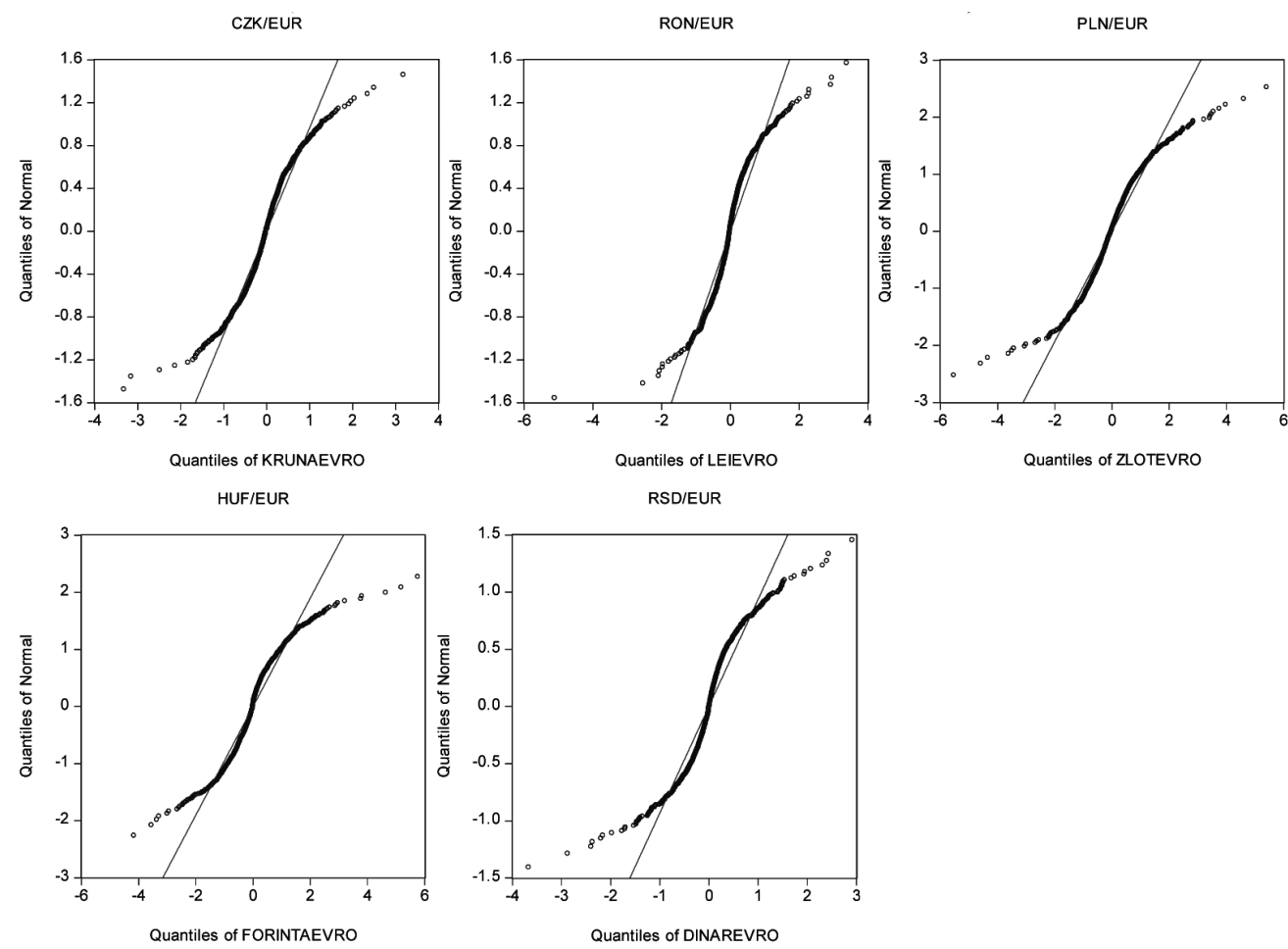

Table 1 indicates that the daily exchange rate returns are not normally distributed. In most cases skewness is evident; kurtosis is in all cases greater than 3 and the Jarque-Bera statistics are highly significant. Negatively skewed distributions are reported for daily exchange rate ruturns of CZK/EUR and RSD/ EUR which indicate appreciation of the currency, while positively skewed distribution are reported for daily exchange rate ruturns of ROL/EUR, PLZ/EUR and HUF/EUR which indicate depreciation of the currency. The coefficient of excess kurtosis is in all cases much greater than 3 indicating the distribution of the returns is leptokurtic, which means that the distribution has fatter tails. The largest coefficient of excess kurtosis is reported for Romanian leu and Serbian dinar and highlights that these exchange rates account for larger deviations in their returns. The results confirm the presence of fat tails, which suggest that the assumption of a normal distribution is not satisfied. ARCH-LM test indicates presence of time varying volatility, and Box-Ljung statistics indicate evidence of autocorrelation in squared standardized residuals. 
Table 1: Descriptive statistics of of daily exchange rate returns

\begin{tabular}{|c|c|c|c|c|c|c|c|}
\hline & Skewness & Kurtosis & JB & $\mathbf{Q}^{2}(\mathbf{1 0})$ & $\mathbf{Q}^{2}(\mathbf{3 0})$ & $\begin{array}{c}\text { ARCH-LM } \\
(\mathbf{1 0})\end{array}$ & $\begin{array}{c}\text { ARCH-LM } \\
(\mathbf{3 0})\end{array}$ \\
\hline CZK/EUR & -0.024 & 9.823 & $\begin{array}{c}6498.36 \\
(0.00)\end{array}$ & $1218.2(0.00)$ & $2059.4(0.00)$ & $508.36(0.00)$ & $591.90(0.00)$ \\
\hline ROL/EUR & 0.013 & 17.676 & $\begin{array}{c}18919.10 \\
(0.00)\end{array}$ & $577.50(0.00)$ & $847.52(0.00)$ & $333.19(0.00)$ & $380.15(0.00)$ \\
\hline PLZ/EUR & 0.321 & 9.553 & $\begin{array}{c}6051.22 \\
(0.00)\end{array}$ & $1293.6(0.00)$ & $2216.6(0.00)$ & $549.94(0.00)$ & $621.83(0.00)$ \\
\hline HUF/EUR & 0.665 & 11.721 & $\begin{array}{c}10773.46 \\
(0.00)\end{array}$ & $1142.6(0.00)$ & $1563.9(0.00)$ & $527.35(0.00)$ & $560.52(0.00)$ \\
\hline RSD/EUR & -0.203 & 13.085 & $\begin{array}{c}11057.86 \\
(0.00)\end{array}$ & $1109.7(0.00)$ & $\begin{array}{c}2466.5 \\
(0.00)\end{array}$ & $523.29(0.00)$ & $686.48(0.00)$ \\
\hline
\end{tabular}

Source: Author's calculations. Note: $\mathrm{P}$ values of coresponding test statistics are given in parentheses. JB represents Jarque-Bera statistics for normality testing, $\mathrm{Q}^{2}$ represents Box-Ljung statistics for testing autocorelation in squared standardized residuals, while $\mathrm{ARCH}-\mathrm{LM}$ test is test of autoregressive conditional heteroscedasticity.

Table 2 shows the results of unit root test for daily exchage rate returns series. The Augmented Dickey-Fuller test and Phillips-Perron test statistics for all exchange rate returns are highly significant, i.e. the values are less then their critical values at $1 \%, 5 \%$ and $10 \%$ level, thereby suggesting the rejection of null hypothesis of the presence of unit root in the return series. Therefore, it is appropiate to examine the return volatility using the original level of the series, i.e. there is no need to difference the data.

Table 2: Unit root test of the daily exchange rates

\begin{tabular}{|c|c|c|c|c|c|c|c|c|}
\hline & \multicolumn{4}{|c|}{ Augmented Dickey-Fuller test } & \multicolumn{3}{c|}{ Phillips-Perron test } \\
\hline & Statistic & \multicolumn{3}{|c|}{ Critical values } & Statistic & \multicolumn{3}{c|}{ Critical values } \\
\hline & & $1 \%$ level & $5 \%$ level & $10 \%$ level & & $1 \%$ level & $5 \%$ level & $10 \%$ level \\
\hline CZK/EUR & $\begin{array}{c}-56.717 \\
(0.00)\end{array}$ & -3.432 & -2.862 & -2.567 & $\begin{array}{c}-56.863 \\
(0.00)\end{array}$ & -3.432 & -2.862 & -2.567 \\
\hline ROL/EUR & $\begin{array}{c}-30.429 \\
(0.00)\end{array}$ & -3.433 & -2.862 & -2.567 & $\begin{array}{c}-37.313 \\
(0.00)\end{array}$ & -3.433 & -2.862 & -2.567 \\
\hline PLZ/EUR & $\begin{array}{c}-36.389 \\
(0.00)\end{array}$ & -3.432 & -2.862 & -2.567 & $\begin{array}{c}-62.301 \\
(0.00)\end{array}$ & -3.432 & -2.862 & -2.567 \\
\hline HUF/ EUR & $\begin{array}{c}-61.102 \\
(0.00)\end{array}$ & -3.432 & -2.862 & -2.567 & $\begin{array}{c}-61.706 \\
(0.00)\end{array}$ & -3.432 & -2.862 & -2.567 \\
\hline RSD/EUR & -31.821 \\
$(0.00)$ & -3.432 & -2.862 & -2.567 & $\begin{array}{c}-35.102 \\
(0.00)\end{array}$ & -3.432 & -2.862 & -2.567 \\
\hline
\end{tabular}

Source: Author's calculations. Note: $P$ values of corresponding test statistics are given in parentheses. The appropriate lags are automatically selected employing Schwarc information criterion. 


\subsection{Empirical results}

Bearing in mind that Box-Ljung autocorrelation test for squared standardized residuals and ARCH/LM tests indicate presence of ARCH effects, we estimate models of conditional autoregressive heteroscedasticity (GARCH type models). Model selection was done according to modified Akaike criteria. Model parameters are calculated using maximum likelihood estimation method. Maximum likelihood estimates of the parameters are obtained by numerical maximization of the log-likelihood function using the BHHH algorithm.

Since the aim of this study is to find the impact of global financial and European sovereign debt crisis on Central and Eastern Europe (CEEC) countries this study included an explanatory variables of global financial crisis and European sovereign debt crisis in the mean and conditional variance equation with intention to find the impact of crisis on the exchange rate returns and volatility.

Conducted empirical test indicate that the return distributions are not characterized by normality. Due to skewness and excess kurtosis of daily financial return distributions, estimates based with assumption that residuals follow normal distribution has its drawbacks. Our results of estimation show that such GARCH type models assuming Student's t distribution of standardized returns is superior measure of downside risk, especially for trading strategies that exhibit negative skewness and excess kurtosis.

Results of estimating ARMA (m,s)-GARCH $(\mathrm{p}, \mathrm{q})$ model, and different types of asymmetric ARMA (m,s)-GARCH (p,q) model with assumption that the residuals follow normal or Student's t distribution suggest the following conclusion (Table 3).

In case of Czech Republic koruna, GARCH $(1,1)$ model with assumption that the residuals have Student's t distribution best describes exchange rate return series. Exchange rate return does not characterize neither AR nor MA component. With the respect to the mean equation, coefficient d1(coefficient of global financial crisis) and d2 (coefficiente of European sovereign debt crisis) suggest that the existence of global financial and European sovereign debt crisis is not significant in influencing exchange rate returns. As far as conditional variance equation concern, value of $\beta$ shows magnitude variance on the current variance and shows magnitude of volatility clustering. The value of $\beta$ coefficient is highly significant which shows that persistence volatility clustering prevails in CZK/EUR exchange rate return. This volatility clustering reveals that once volatility persists it takes long time to become smooth. Last two coefficientes of this model is concernd with recent global financial and European sovereign debt crisis. The coefficient of global financial crisis is positive and significant while coefficient of European sovereign debt crisis is statistically insignificant. Results indicate that recent global financial crisis positively hit volatility of exchange rate return by $0.6 \%$.

In case of Romanian lea, IGARCH $(1,1)$ model with assumption that the residuals have Student's t distribution best describes exchange rate return series.

Vol. 12, No 1, 2015: 105-122 
In the mean equation auto regression component of the first order is significant, but estimated value of the auto regression parameter is very small. With the respect to the mean equation, coefficient of global financial crisis suggests that the existence of global financial is not significant in influencing exchange rate returns, while coefficient of European sovereign debt crisis is positive and statistically significant. Result indicates that European sovereign debt crisis influencing in depreciation of Romanian lea by $6 \%$. As far as conditional variance equation concern, the value of coefficients $\alpha$ and $\beta$ are statistically significant at $5 \%$ level. The IGARCH model also shows that variances are stationary and persistence of volatility will remain forever. Last two coefficientes of this model is concernd with recent global financial and European sovereign debt crisis. The coefficient of global financial crisis is positive and significant while coefficient of European sovereign debt crisis is statistically insignificant. Results indicate that recent global financial crisis positively hit volatility of exchange rate return by $0.2 \%$.

In case of Polish zloty, TGARCH $(1,1)$ model with assumption that the residuals have Student's t distribution best describes exchange rate return series. In the mean equation auto regression component of the first order is significant, but estimated value of the auto regression parameter is very small. With the respect to the mean equation, coefficient of global financial crisis suggests that the existence of global financial is not significant in influencing exchange rate returns, while coefficient of European sovereign debt crisis is positive and statistically significant. Result indicates that European sovereign debt crisis influencing in depreciation of Polish zloty by $8 \%$. As far as conditional variance equation concern the value of $\beta$ coefficient is highly significant which shows that persistence volatility clustering prevails in PLZ/EUR exchange rate return. Value of $\gamma$ coefficient is statistically significant which show that asymmetry information impact exists in this exchange rate return series and that negative shock has stronger impact on the volatility than the positive shock. Last two coefficientes of this model is concernd with recent global financial and European sovereign debt crisis. The coefficient of global financial crisis is positive and significant while coefficient of European sovereign debt crisis is statistically insignificant. Results indicate that recent global financial crisis positively hit volatility of exchange rate return by $2.4 \%$.

In case of Hungarian forint, EGARCH $(1,1)$ model with assumption that the residuals have Student's t distribution best describes exchange rate return series. Exchange rate return does characterize neither AR nor MA component. With the respect to the mean equation, coefficient $\mathrm{d} 1$ (coefficient of global financial crisis) and d2 (coefficiente of European sovereign debt crisis) suggest that the existence of global financial and European sovereign debt crisis is not significant in influencing exchange rate returns. As far as conditional variance equation concern, value of $\beta$ shows magnitude variance on the current variance and shows magnitude of volatility clustering. The value of $\beta$ coefficient is highly significant which shows that persistence volatility clustering prevails in HUF/ 
EUR exchange rate return. The EGARCH variance equation indicates that there exists the asymmetric behaviour in volatility which means that positive shocks are effecting differently, then the negative on volatility. Last two coefficientes of this model is concernd with recent global financial and European sovereign debt crisis. The coefficient of global financial crisis and European sovereign debt crisis is not significant in influencing exchange rate volatility.

In case of Serbian dinar, IGARCH $(1,1)$ model with assumption that the residuals have Student's t distribution best describes exchange rate return series. In the mean equation auto regression component of the first order is significant, but estimated value of the auto regression parameter is very small. However, the values of $Q$ statistics with p-value less than $5 \%$ of the standardized residuals in estimated ARMA $(1,1)$ model imply that serial correlation remained in the standardized residuals and that conclusion regarding the impact of financial and sovereing crisis is not accurate.

Table 3: Parameter estimation of GARCH models with student's $t$ distribution of the standardized residuals

\begin{tabular}{|c|c|c|c|c|c|}
\hline \multicolumn{6}{|c|}{ Student's t distribution } \\
\hline & CZK/EUR & ROL/EUR & PLZ/EUR & HUF/EUR & RSD/EUR \\
\hline \multicolumn{6}{|c|}{ Mean equation } \\
\hline Constant & $-0.012(0.01)$ & $-0.008(0.07)$ & $-0.026(0.00)$ & $0.011(0.00)$ & $0.033(0.00)$ \\
\hline $\mathrm{AR}(1)$ & & $0.097(0.00)$ & $-0.059(0.00)$ & & $0.278(0.00)$ \\
\hline \multicolumn{6}{|l|}{$\mathrm{MA}(1)$} \\
\hline \multicolumn{6}{|l|}{$\mathrm{d} 1$} \\
\hline $\mathrm{d} 2$ & & $0.060(0.03)$ & $0.080(0.05)$ & & \\
\hline \multicolumn{6}{|c|}{ Volatility equation } \\
\hline $\mathrm{c}$ & $0.002(0.00)$ & & $0.008(0.00)$ & $-0.116(0.00)$ & \\
\hline$a$ & $0.063(0.00)$ & $0.142(0.00)$ & $0.102(0.00)$ & & $0.122(0.00)$ \\
\hline$\beta$ & $0.921(0.00)$ & $0.857(0.00)$ & $0.900(0.00)$ & $0.996(0.00)$ & $0.877(0.00)$ \\
\hline$\theta$ & & & & $0.153(0.00)$ & \\
\hline$\gamma$ & & & $-0.058(0.00)$ & $0.052(0.00)$ & \\
\hline \multicolumn{6}{|l|}{$\delta$} \\
\hline $\mathrm{d} 1$ & $0.006(0.03)$ & $0.002(0.02)$ & $0.024(0.02)$ & & \\
\hline $\mathrm{d} 2$ & & & & & \\
\hline \multicolumn{6}{|c|}{ Number of degrees of freedom } \\
\hline $\mathrm{V}$ & 5 & 5 & 8 & 4 & 6 \\
\hline \multicolumn{6}{|l|}{ Specification tests } \\
\hline $\mathrm{Q} 2(30)$ & $22.92(0.81)$ & $23.89(0.73)$ & $36.80(0.15)$ & $0.06(1.00)$ & $31.08(0.36)$ \\
\hline $\mathrm{Q}(30)$ & $26.76(0.63)$ & $31.72(0.33)$ & $25.55(0.64)$ & $12.88(0.99)$ & $50.90(0.007)$ \\
\hline $\mathrm{JB}$ & $2970.36(0.00)$ & $3624.13(0.00)$ & $447.02(0.00)$ & $9998(0.00)$ & $1022.53(0.00)$ \\
\hline ARCH (10) & $9.47(0.48)$ & $10.70(0.38)$ & $17.89(0.05)$ & $0.020(1.00)$ & $18.49(0.04)$ \\
\hline
\end{tabular}

Source: Author's calculations

Vol. 12, No 1, 2015: 105-122 


\section{Conclusion}

The aim of this study is to envisage the impact of global financial (GFC) and European sovereign debt crisis (ESDC) on foreign exchange markets of emerging countries in Central and Eastern Europe CEEC countries (Czech Republic, Hungary, Romania, Poland and Serbia). The dataset consists of the daily returns of exchange rates on Czech Republic koruna (CZK), Hungarian forint (HUF), Romanian lea (ROL), Polish zloty (PLZ) and Serbian dinar (RSD), all against the euro. Analysis was conducted for the period $3^{\text {rd }}$ January 2000 to 15 th April 2013, $3^{\text {rd }}$ January 2003 to $15^{\text {th }}$ April 2013 for RSD/EUR and $3^{\text {rd }}$ January 2005 to $15^{\text {th }}$ April 2013 for RON/EUR in respect. Econometric methodology is based on different version of GARCH specification. The influence of global financial crisis and European sovereign debt crisis in model has been seen by the use of dummy variables.

Overall results imply that global financial crisis has no impact on exchange rate returns in selected CEEC countries, while European sovereign debt crisis influencing in depreciation of Polish zloty by $8 \%$ and Romanian lea by $6 \%$. Estimated obtained by our calculation imply that global financial crisis increased enhanced volatility on exchange rate returns of Czech koruna, Romanian lea and Polish zloty. Moreover, results of empirical analysis imply that this impact has the strongest influence in volatility on exchange rate returns of Polish zloty.

\section{Reference}

- Andersen, T. G., Bollerslev, T., Diebold, F. X., \& Labys, P. (2000): „Exchange Rate Returns Standardized by Realized Volatility Are (Nearly) Gaussian“, Multinational Finance Journal, 4, 159-179.

- Bollerslev, T. (1986): „Generalized autoregressive conditional heteroskedasticity", Journal of Econometrics 31 , 307-327.

- Bollerslev, T., Engle, R., \& Nelson, D. (1994): „ARCH Models“, Handbook of Econometrics, Volume IV. Amsterdam: North Holland: ed. Engle, R; McFadden, D.

- Chang, K.-H., Cho, K. Z., \& Hong, M.-G. (2010): „Stock Volatility, Foreign Exchange Rate Volatility and the Global Financial Crisis", Journal of Economic Research, 15(2010) , 249-272.

- Chong, C. W., \& Chun, L. S. (2002): „Modeling the volatility of currency exchange rate using GARCH model", Petranka Journal of Social Science \& Humanities, 10(2), 85-95.

- $\quad$ Ding, Z., Engle, R. F., \& Granger, C. W. (1993): „A long memory property of stock market returns and a new model“, Journal of Empirical Finance 1, 83-106. 
- Engle, R. F. (1982): „Autoregressive Conditional Heteroscedasticity with Estimates of the Variance of United Kingdom Inflation“, Econometrica $50,987-1007$.

- $\quad$ Fidrmuc, J., \& Horvath, R. (2007): Volatility of exchange rates in selected new EU members: evidence from daily data, CESifo working paper, No. 2017.

- Frommel, M. (2010): „Volatility Regimes in Central and Eastern European Countries Exchange Rates", Finance a uver-Czech Journal of Economics and Finance, $60,1-21$.

- Kamal, Y., Hammmad-Ul-Haq, Ghani, U., \& Khan, M. M. (2012): „Modeling the exchange rate volatility, using generalized autoregressive conditionally heteroscedastic (GARCH) type models: Evidence from Pakistan", African Journal of Business Management, Vol. 6(8), 2830-2838.

- Kobor, A., Szekely, I. P. (2004): „Foreign Exchange Market Volatility in EU A ccession Countries in the Run-Up to Euro Adoption: Weathering Uncharted Waters", Economic Systems, 28, 337-352.

- Kočenda, E., Valachy, J. (2006): „Exchange rate volatility before and after regime shift: A new measure and new evidence from transition", Journal of Comparative Economics, 34, 727-753.

- $\quad$ Longmore, R., Robinson, W. (2004): Modeling and Forecasting Exchange Rate Dynamics: An Application of Asymmetric Volatility Models, Bank of Jamaica, Researche Services Department, Working Paper WP 2004/03.

- McMillan, D. G., Thupayagale, P. (2010): „Evaluating Stock Index Return Value-at-Risk Estimates in South Africa: Comaparative Evidence for Symmetric, Asymmetric and Long Memory GARCH Models“, Journal of Emerging Market Finance, 9 , 325-345.

- Miletić, S., Korenak, B., Vukosavljević, D. (2013): „Impact of global financial and european sovereign debt crisis on CEEC stock markets: an application of symmetric and asymmetric GARCH type models", $X L$ Symposium on Operational Research, SYM-OP-IS 2013, Zlatibor, 8-12 September 2013, (23-29)

- Nelson, D. B. (1991): „Conditional Heteroscedasticity in Asset Return: A New Approach“, Econometrica, 52(2), 347-70.

- Olowe, R. A. (2009): „Modelling Naira/Dollar Exchange Rate Volatility: Application of GARCH And Asymmetric Models", International Review of Businesss Research Papers, Vol. 5, No. 3, 377-398.

- Poon, S., Granger, C. (2003): „Forecasting Volatility in Financial Markets: A Review“, Journal of Economic Literature, Vol. 41, 478-539.

- Schnabl, G. (2008): „Exchange rate volatility and growth in small open economies at the EMU periphery", Economic Systems, 32.

- Suliman, Z. S. (2012): „Modeling Exchange Rate Volatility using GARCH Models: Empirical Evidence from Arab Countries", International Journal of Economics and Finance, Vol. 4, No.3, 216-229. 
- Todea, A., Platon, D. (2012): „Sudden Changes in Volatility in Central and Eastern European Foreign Exchange Markets", Romanian Journal of Economic Forecasting, 2/2012, 38-51.

- Zakoian, J. M. (1994): „Treshold Heteroskedastic Models“, Journal of Economic Dynamics and Control 18, 931-955. 
Visoka škola za poslovnu ekonomiju i preduzetništvo, Beograd

\title{
MODELIRANJE VOLATILNOSTI DEVIZNOG KURSA U ZEMLJAMA CENTRALNE I ISTOČNE EVROPE: UTICAJ GLOBALNE FINANSIJSKE KRIZE I KRIZE JAVNOG DUGA
}

\begin{abstract}
S a ž e t a k
Osnovni cilj ovog rada je da ispita uticaj globalne finansijske krize i krize javnog duga na devizna tržišta zemalja Centralne i Istočne Evrope (Češka, Mađarska, Rumunija, Poljska i Srbija). Dnevni prinosi deviznih kurseva (češka kruna, mađarska forinta, rumunski lej, poljski zlot i srpski dinar, svi u odnosu na evro) analizirani su za period od 3. januara 2000. do 15. aprila 2013. godine. Kako bi se ispitao uticaj globalne finansijske krize i krize javnog duga, kreirane su veštačke promenljive. Ocenjeni rezultati pokazuju da globalna finansijska kriza nije imala uticaj na prinose deviznih kurseva posmatranih zemalja, dok je kriza javnog duga uticala na depresijaciju deviznih kurseva poljskog zlota $8 \%$ i rumunskog leja $6 \%$. Ocenjeni rezultati, takođe, ukazuju na to da je globalna finansijska kriza uticala na povećanje volatilnosti deviznih kurseva (češke krune, rumunskog leja i poljskog zlota), pri čemu je uticaj krize bio najizraženiji u slučaju poljskog zlota.

Ključne reči: devizni kurs, volatilnost, globalna finansijska kriza, kriza javnog duga, zemlje Centralne i Istočne Evrope
\end{abstract}


